\title{
SHORT-TERM IMPACTS OF FIRE-MEDIATED HABITAT ALTERATIONS ON AN ISOLATED BIGHORN SHEEP POPULATION
}

\author{
Justin G. Clapp ${ }^{1,2^{*}}$ and Jeffrey L. Beck ${ }^{1}$ \\ ${ }^{1}$ Department of Ecosystem Science and Management, University of Wyoming, \\ Department 3354, 1000 East University Avenue, Laramie, Wyoming 82071, USA \\ ${ }^{2}$ Current address: Wyoming Game and Fish Department, \\ 260 Buena Vista Drive, Lander, Wyoming 82520, USA \\ *Corresponding author: Tel.: +1-307-332-2688; e-mail: justin.clapp@wyo.gov
}

\begin{abstract}
Habitat alterations may improve and expand wildlife habitats, and bolster waning wildlife populations. We used global positioning system (GPS) locations to monitor 38 bighorn sheep (Ovis canadensis Shaw) that were translocated to the Seminoe Mountains, Wyoming, USA, in 2009 and 2010, and 24 bighorns captured in 2011 to investigate short-term impacts of prescribed fires and wildfires that covered $\sim 24 \%$ of the study area in 2011 and 2012. We quantified home range distributional changes, resource selection, and survival of bighorn sheep from 2009 to 2013. Although bighorns expanded home ranges and increased proportional use of fire-treated areas, there was no overall selection for fire-treated areas. Bighorn survival decreased by over $30 \%$ after fires in 2012 that were accompanied by severe drought. Prescribed fires conducted under favorable conditions (2011) induced potentially positive bighorn responses including high survival and increased use of treated areas. Fires during drought conditions were more widespread with little vegetative response (2012) and coincided with in-
\end{abstract}

\section{RESUMEN}

Las alteraciones del hábitat pueden mejorar y ampliar los hábitats de vida silvestre, y reforzar las menguante poblaciones de vida silvestre. Utilizamos ubicaciones del Sistema de Posicionamiento (GPS) para monitorear a 38 borregos cimarrónes (Ovis canadensis Shaw), que fueron trasladadas a las Montañas Seminoe, Wyoming, EEUU, en 2009 y 2010, y 24 cimarrones capturados en 2011 para investigar los efectos a corto plazo de los incendios e incendios prescritos que cubrían $\sim 24 \%$ del área de estudio en 2011 y 2012. Se cuantificaron los cambios distributivos del ámbito hogareño, la selección de recursos, y la supervivencia de cimarrónes entre 2009 y 2013. A pesar de que los cimarrones expandieron sus áreas de distribución e hicieron un mayor uso proporcional de las áreas tratadas por el fuego, no hubo selección general para las zonas tratadas con fuego. La supervivencia de los borregos cimarrones disminuyó en más del $30 \%$ después de los incendios del 2012, que fueron acompañados por una grave sequía. Los fuegos prescritos realizados en condiciones favorables (2011) indujeron respuestas potencialmente positivas, incluyendo una alta supervivencia y mayor uso de las áreas tratadas. Los incendios durante las condiciones de sequía fueron más generalizados con poca respuesta vegetativa (2012) y coincidieron con una mayor mortalidad cima- 
creased bighorn mortality in spring 2013. Dead bighorns with poor body condition had high home range overlap with burned areas. We suggest that large fires coupled with unfavorable weather conditions rendered bighorns unable to access adequate forage to meet nutritional requirements. Because impacts of fires on bighorn populations are highly dependent on ensuing vegetative recovery, consideration should be given to the timing, extent, and spatial coverage of prescribed fires. Therefore, we recommend conducting prescribed fires before bighorn reintroductions, or conducting prescribed fires on a relatively small scale and on a rotational basis to avoid reducing foraging options. rrón en la primavera del 2013. Los cimarrones muertos con malas condiciónes corporales se superpusieron con las áreas quemadas. Sugerimos que los grandes incendios, junto con las condiciones climáticas desfavorables impidieron a los cimarrones acceder a forraje suficiente para satisfacer sus requisitos nutricionales. Debido a los impactos de los incendios en las poblaciones de borregos cimarrones y de que estas son altamente dependientes de la recuperación vegetativa subsiguiente, se debe considerar el tiempo, alcance y cobertura espacial de las quemas prescritas. Por lo tanto, se recomienda la realización de quemas prescritas antes de la reintroducción de los borregos cimarrones, o llevar a cabo incendios prescritos en una escala relativamente pequeña y en forma rotativa para evitar la reducción de las opciones de búsqueda de alimento de esta forma de vida silvestre.

Keywords: bighorn sheep, global positioning system, Ovis canadensis, prescribed burning, resource selection, survival, translocation, wildfire, Wyoming

Citation: Clapp, J.C., and J.L. Beck. 2016. Short-term impacts of fire-mediated habitat alterations on an isolated bighorn sheep population. Fire Ecology 12(3): 80-98. doi: 10.4996/ fireecology. 1203080

\section{INTRODUCTION}

Habitat alterations are often implemented to improve and expand wildlife habitats (Osborne and Seddon 2012), and may be applied in an effort to bolster waning wildlife populations. While habitat evaluations are often conducted after alterations occur, assessment of wildlife responses to treatments provides key information on how habitat treatments impact targeted animals (Van Dyke and Darragh 2007). To identify impacts to target populations, distributional response may be assessed, often measured by changes in animal space use and habitat selection. However, distributional responses can be limiting if not assessed in concert with demographic response to identify not only if habitat alterations result in selection for treated areas or expanded space use, but actually improve the overall fitness and productivity of the targeted population.

Because many bighorn sheep (Ovis canadensis Shaw) populations migrate through extensive elevational gradients, habitat suitability models for the Rocky Mountains, USA, suggest reintroducing bighorn into large patches of habitat that promote movements and migrations to increase the success rate of translocations (Singer et al. 2000). However, long-distance migrations do not occur among isolated or non-migratory bighorn populations restricted within habitat surrounded by a matrix of unsuitable landscapes. For instance, some desert bighorn (O.c. nelsoni) populations use seasonal ranges separated by as little as $2 \mathrm{~km}$ to $30 \mathrm{~km}$ annually (Ough and deVos 1986, Bleich et al. 1990). Consequently, bighorn sheep concentrated to restricted habitat, 
especially on winter range, may be more susceptible to disease, increased predation, limited genetic connectivity, and overutilization (Risenhoover et al. 1988). Thus, the standard recommended is to eliminate tall vegetation through burning or easements to open restrictive habitats and encourage use of movement corridors (Smith et al. 1999, Singer et al. 2000).

Past studies have documented variable increases in forage nutritional quality and production in various shrub and grassland habitats following burning (DeWitt and Derby 1955, Seip and Bunnell 1985, Cook et al. 1994, Van Dyke and Darragh 2007). Consequently, prescribed burning is used as a management tool to benefit bighorn sheep and has been shown to improve diet quality and foraging efficiency (Hobbs and Spowart 1984, McWhirter et al. 1992). In addition, open habitat created by fire may establish movement corridors that encourage dispersal to previously underused habitats (Risenhoover et al. 1988). While these studies have examined changes in vegetation in burned and unburned areas, a deficiency persists in evaluating the effects of fire on bighorn sheep demography, highlighting the need to further investigate in situ demographic response of bighorns to impacts of fire.

Our study aimed to quantify short-term impacts of fire-mediated habitat alterations to a recently translocated bighorn population in the Seminoe Mountains, located in south-central Wyoming, USA. These habitat alterations included two prescribed fires applied within the study area (spring 2011 and 2012), as well as an unanticipated wildfire that occurred late in the study. We collected global positioning system (GPS) location data from radio-collared bighorn sheep in the Seminoe Mountains from 2009 to 2013 that included three translocation events (Dec 2009, Jan 2010, and Dec 2010) as well as a capture event (Dec 2011) within the study area after the initiation of prescribed fires. Our specific objectives were to
(1) identify changes in bighorn distribution, (2) investigate potential habitat selection for fire-treated areas, and (3) compare survival response of bighorn sheep before and after fire events. We predicted that bighorn sheep would expand distribution and select for treated habitat after fires in response to a combination of increased forage quality and reduced shrubby and forested habitat visual barriers that had previously restricted bighorns. We also predicted commensurate survival with favorable habitat improvements.

\section{METHODS}

\section{Study Area}

The Seminoe Mountains $\left(42^{\circ} 10^{\prime} \mathrm{N}, 106^{\circ}\right.$ $56^{\prime} \mathrm{W}$ ) are located approximately $40 \mathrm{~km}$ north of Sinclair, Wyoming, USA (Figure 1). Topography (elevation range from $1830 \mathrm{~m}$ to $2500 \mathrm{~m})$ in the study area $\left(\sim 85 \mathrm{~km}^{2}\right)$ ranges from long draws and ridges in the western portion to nearly vertical cliffs where the North Platte River flows northerly through the range. Land status includes $80 \%$ federal, 10\% state, and $10 \%$ private lands. Primary vegetative cover types include sagebrush (Artemisia spp. L.)-dominated grassland and conifer with a mixed shrub understory intermixed with mountain shrub, riparian meadow, and riparian broadleaf cover types. Dominant coniferous trees include limber (Pinus flexilis James), lodgepole ( $P$. contorta Douglas ex Loudon), and ponderosa ( $P$. ponderosa Lawson \& $\mathrm{C}$. Lawson) pines; and Rocky Mountain juniper (Juniperus scopulorum Sarg.); and deciduous tree species include chokecherry (Prunus virginiana L.), narrowleaf cottonwood (Populus angustifolia James), and quaking aspen (Рориlus tremuloides Michx.). Shrub species include antelope bitterbrush (Purshia tridentata [Pursh] DC.), big sagebrush (Artemisia tridentata Nutt.), and birchleaf mountain mahogany (Cercocarpus montanus Raf.). Hiatt (1997) provides lists of common grass and forb spe- 


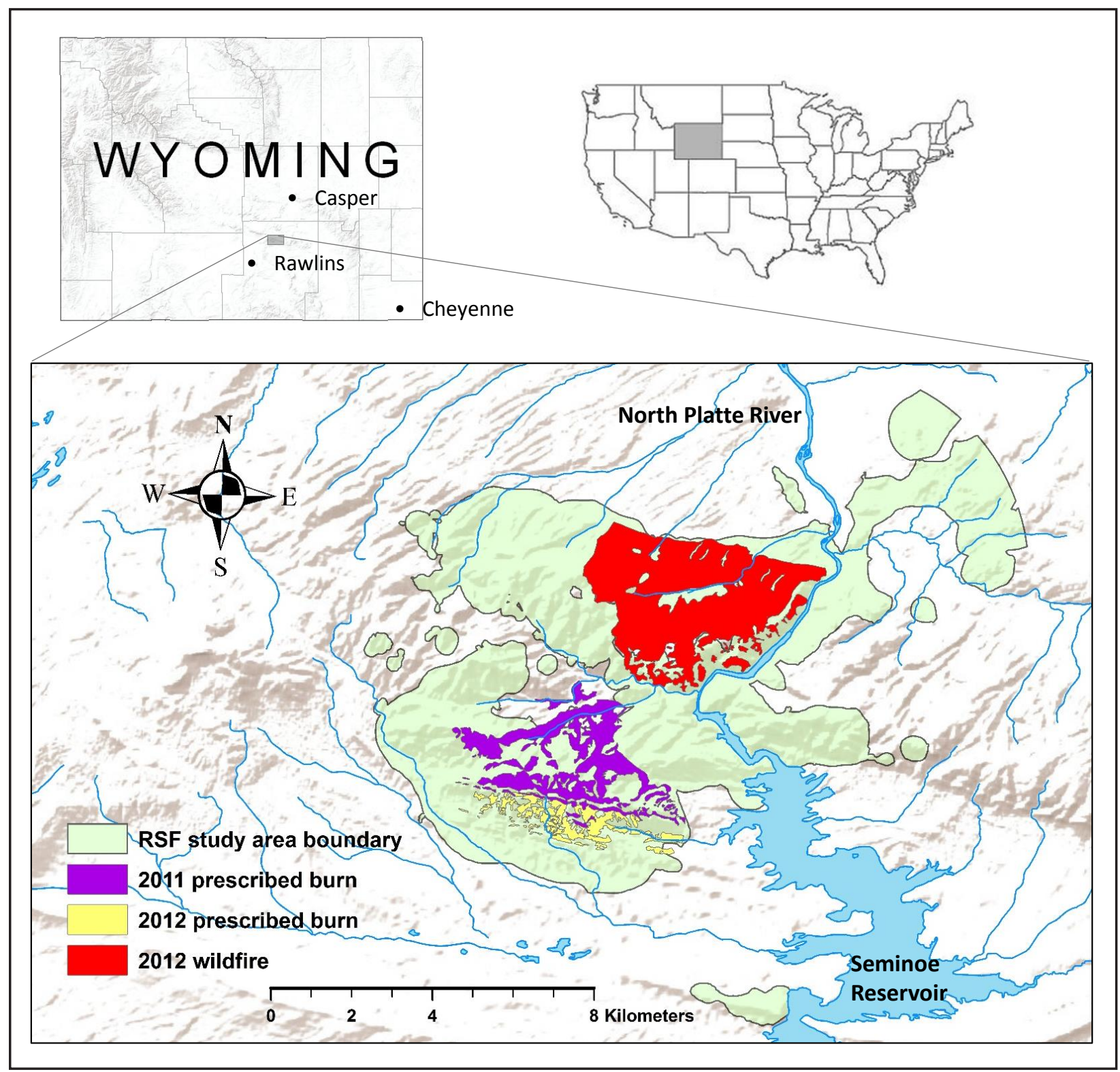

Figure 1. Study area map including RSF study area $\left(86.4 \mathrm{~km}^{2}\right)$ boundaries and fire events $\left(20.1 \mathrm{~km}^{2}\right)$ from 2011 to 2012 in the Seminoe Mountains, south-central Wyoming, USA.

cies for the study area. The $30 \mathrm{yr}$ (1981 to 2010) average annual precipitation was $36 \mathrm{~cm}$ (range $=23 \mathrm{~cm}$ to $49 \mathrm{~cm}$ ), with most precipitation occurring in spring. The $30 \mathrm{yr}$ (1981 to 2010) average annual temperature was $7^{\circ} \mathrm{C}$ (range $3{ }^{\circ} \mathrm{C}$ to $8^{\circ} \mathrm{C}$ ), resulting in 70 to 90 frostfree days, with $45 \%$ of annual precipitation falling as snow (Western Regional Climate Center 2013). High winds are also common in the Seminoe area, especially on exposed slopes and ridges.

\section{Capture of Bighorn Sheep and Habitat Alterations}

In a reintroduction effort from December 2009 to December 2010, 52 bighorn sheep (40 female $[\mathrm{F}], 12$ male $[\mathrm{M}]$ ) were translocated to the Seminoe Mountains from two sites in eastern Oregon and a single site in north-central Wyoming. Helicopter net-gunning was used to capture all bighorns, which were processed, marked, and translocated following state agen- 
cy (Oregon Department of Fish and Wildlife [Foster 2005], Wyoming Game and Fish Department [WGFD] Chapter 10-1535 and Chapter 33-750 permits) approved protocols, and complied with guidelines published by the American Society of Mammalogists (ASM; Sikes and Gannon 2011). Animals were marked using self-piercing metal or plastic ear tags unless previous ear tags were evident, and 40 store-on-board GPS collars (13 GEN III, model TGW3500 collars from Telonics, Inc., Mesa, Arizona, USA; and 27 model G2110D collars from Advanced Telemetry Systems [ATS], Isanti, Minnesota, USA. ) were affixed to $31 \mathrm{~F}$ and $9 \mathrm{M}$ bighorn sheep. GPS data were collected from translocated bighorns through spring 2011.

Prescribed burning initiated by the Bureau of Land Management was conducted in 2011 and 2012 in the southern portion of the study area. Each spring, separate burns targeted dense shrub communities consisting of mountain mahogany and juniper and encroaching timber potentially limiting visibility and movement of bighorn sheep (Risenhoover et al. 1988, Johnson and Swift 2000), but these burns were also intended to improve overall forage quality in the study area. Spring ignitions resulted in mosaic burn patterns around snow cover and low fuel load areas, and totaled $\sim 7.5 \mathrm{~km}^{2}$. Field observations revealed favorable landscape conditions through summer 2011, identified by positive vegetative responses in grass, forb, and shrub communities. A lightning-ignited wildfire also occurred in July 2012 that burned $\sim 12.6 \mathrm{~km}^{2}$ of the northern portion of the study area. This uncontrolled wildfire occurred during extreme drought conditions, and impacted more habitat than the prescribed fires. Likely due to drier conditions and mid-summer ignition, this wildfire also consumed most shrub and grass communities, resulting in large expanses of bare ground, and left little area unburned within the extent of the fire (no mosaic burn patterns). Poor vegetative response of plant com- munities was identified after the wildfire, with little regrowth identified near the end of the study in spring 2013. The combined area of these prescribed and wildfire-mediated habitat alterations resulted in $\sim 20.1 \mathrm{~km}^{2}$ or $\sim 24 \%$ of treated habitat within the study area (Figure 1).

On 2 and 3 December 2011, $20 \mathrm{~F}$ and $5 \mathrm{M}$ bighorns were captured in the study area via helicopter net-gunning, processed, and released on-site following ASM guidelines (Sikes and Gannon 2011), University of Wyoming Institutional Animal Care and Use Committee approved protocols (no. 12012011), and WGFD Chapter 33-750 permit. Twenty-five refurbished GPS collars (Telonics $=4$, ATS $=$ 21) were deployed on these animals to collect location data until they remotely detached in June 2013. This capture included bighorns that were previously collared and released in translocation efforts $(n=16)$, bighorns not fitted with GPS collars when translocated $(n=$ $4)$, and bighorns born in the study area $(n=5)$.

\section{Home Range Analysis}

We used GPS location data to estimate bighorn home ranges to describe distributions in relation to fire-treated areas and to identify changes in home range size after fire events. We standardized location data gathered from each bighorn to include one GPS location every five hours (matching the maximum GPS fix-rate schedule of transmitters from all captures), and censored initial movements to allow bighorns to acclimate after translocation or capture releases (range $=0$ days to 70 days; Clapp et al. 2014). We chose the "BBMM" package (Nielson et al. 2013) in the R statistical environment ( $\mathrm{R}$ Development Core Team 2012) as a home range estimator to create Brownian bridge movement models (BBMM; Horne et al. 2007) to estimate utilization distributions (UD) for each bighorn sheep (Clapp and Beck 2015). We used a sample of 24 bighorn sheep that collected location data after the initiation of fires $(19 \mathrm{~F}, 5 \mathrm{M})$ to investigate 
the amount of home range area that overlapped fire-treated areas. We digitized areas impacted by fire-mediated habitat alterations using satellite imagery provided by Apollo Mapping (Boulder, Colorado, USA) and with aerial photography acquired shortly after each fire event, and we quantified the proportional overlap of each distribution with fire-treated areas at $50 \%$ and $95 \%$ home range contours. We report descriptive statistics including means, standard errors (SE), and ranges of proportional overlap with fire-treated areas.

We next used a subsample of 16 radio-collared bighorn sheep (12 F, $4 \mathrm{M}$ ) from the 24 captured within the study area to identify changes in home range distributions after fires. GPS transmitters attached to these bighorns collected location data prior to the initiation of fires that occurred in early May 2011 (pre fire), and subsequent recaptures of these animals continued data collection through June 2013 (post fire). For consistency, we standardized the duration of GPS data acquired from each animal by matching ordinal dates (starting 1 January and ranging from 1 to 366) when data were collected before and after the initiation of fires. We created a pair of UDs for each animal, and summarized relative change in home range size by dividing post-fire area by pre-fire area $\left(A_{2} \div A_{1}\right)$. We conducted one sample $t$-tests to identify relative changes in bighorn distribution at $50 \%$ and $95 \%$ home range contours. We implemented $\alpha=0.05$ for statistical significance and report mean, standard error, and range for each estimate. We conducted home range analyses and data management in R 2.15.3 (R Development Core Team 2012).

\section{Resource Selection Analysis}

In our resource selection function (RSF) analysis, we used RSF modeling to identify a specific predictor variable-selection of fire-altered habitats-while allowing other habitat components to compete as predictors in model selection and comparison of effect sizes. We constructed a single model from data gathered throughout the study and tested for significance of an interaction between prefire or post-fire location data (discrete binary predictor variable) and the distance to treated areas (continuous predictor variable).

Acquisition of GPS locations was high in our study, averaging over $90 \%$ success for collared bighorns, which alleviated potential bias associated with low GPS fix success (Nielson et al. 2009). Resource selection can be identified when animals utilize a resource disproportionate to what is available on the landscape (Hall et al. 1997, Manly et al. 2002). To delineate availability in our analysis, we merged 95\% contours from BBMM home range estimates of each individual throughout the duration of the study (Dec 2009 to June 2013), eliminating likely non-habitats. Because the purpose of the RSF was to specifically identify selection of treated habitat, we refined availability to areas within a $5 \mathrm{~km}$ buffer from the perimeter of treated areas, where habitat alterations had a higher likelihood of influencing bighorn habitat selection. This procedure eliminated areas occupied by individuals that dispersed or spent time away from the study area.

To quantify RSF response, we generated circular sampling units with a radius of $150 \mathrm{~m}$ that were small enough to isolate and represent habitat components across the landscape (Millspaugh et al. 2006, Sawyer et al. 2006), yet large enough to encompass adequate volume of locations to determine intensity of use and approximate error distributions (Sawyer et al. 2006, 2009), and that exceeded the expected spatial error associated with GPS location acquisition (Nielson and Sawyer 2013). We randomly distributed 2000 sampling units across the study area to ensure independence in sampling unit response (Sawyer et al. 2009), allowing units to overlap and locations to fall outside or within one or more independent sampling units. We then quantified intensity of use as the number of locations within each sampling unit. We used a negative binomial general linear model because count data 
exhibited over-dispersion from a Poisson distribution, in which variance exceeded the mean of the response (White and Bennetts 1996). The negative binomial regression model took the form:

$$
\ln \left[E\left(t_{i}\right)\right]=\beta_{0}+\beta_{1} x_{1 i}+\beta_{2} x_{2 i} \ldots+\beta_{n} x_{n i},
$$

where $E\left(t_{i}\right)$ was the expected number of locations within sampling unit $i ; \beta_{0}$ represented the intercept term; $\beta_{1}, \beta_{2}, \ldots, \beta_{n}$ represented estimated coefficients; and $x_{1 i}, \ldots, x_{n i}$ were covariate values measured across respective sampling units (Nielson and Sawyer 2013). To assess resource selection, we included habitat variables likely to impact bighorn populations, and quantified habitat layers (i.e., aspect, elevation, escape terrain, slope) using $10 \mathrm{~m} \times 10$ $\mathrm{m}$ resolution digital elevation data (National Elevation Dataset, US Geologic Survey, Sioux Falls, South Dakota, USA) in a Geographic Information System framework (ArcMap 10.1; Table 1). Distance to burned areas was measured from the center of each sampling unit to the nearest edge of digitized burned areas within the area defined as available, regardless of whether fires had yet occurred (Table 1).
We assessed predictor variable correlations via Pearson's correlation matrices and restricted highly correlated variables from entering model selection $(|r|>0.70)$ by including top performing variables using Akaike's Information Criterion (AIC). We further assessed multicollinearity by calculating predictor variable tolerances in top performing models $(\mathrm{r}=0.44-$ 0.88 ), ensuring that they exceeded recommended minimum tolerance thresholds (e.g., $>0.10$; Tabachnick and Fidell 2001). We standardized continuous predictor variables (by $z$-score) to facilitate direct comparison of predictor variable influences in coefficient plots.

To allocate location data into the pre-fire or post-fire binary predictor (pre.post in Table 1) used in the model, we projected pooled bighorn locations collected before fires, quantified a response variable as a measure of intensity of use, and assigned each of the 2000 sampling units the binary predictor "pre-fire" (among the other calculated habitat variable values). We repeated this procedure using location data gathered after the initiation of fires labeled "post-fire." This resulted in 4000 rows of data, with intensity of use equally represented in RSF model response.

Table 1. Descriptions of candidate habitat variables used to model bighorn resource selection in the Seminoe Mountains, Wyoming, USA, from 2009 to 2013.

\begin{tabular}{ll}
\hline Covariates & \multicolumn{1}{c}{ Description } \\
\hline aspect & Dominant cardinal direction within each sampling unit. North used as reference factor. \\
dist_burn & Sampling unit center to nearest $(\mathrm{m})$ burned habitat edge calculated after fire events. \\
dist_escp & Sampling unit center to nearest $(\mathrm{m})$ escape terrain $\left(\text { slope }>27^{\circ}\right)^{*}$. \\
dist_road & Sampling unit center to nearest $(\mathrm{m})$ road. \\
dist_water & Sampling unit center to nearest $(\mathrm{m})$ perennial water source. \\
elev & Average elevation $(\mathrm{m})$ within sampling unit . \\
slope & Average slope $\left({ }^{\circ}\right)$ within sampling unit. \\
pre.post & Binary variable $(1=$ after fire treatment; $0=$ prior to fire treatment). \\
Int & Interaction term $($ pre.post $\times$ dist_burn). \\
\hline
\end{tabular}

*(DeCesare and Pletscher 2006) 
We identified seasonal timeframes similar to other low-elevation, non-migratory bighorn sheep herds in Wyoming as summer (June 1 to Oct 31) and winter (Nov 1 to April 30) seasons (Kauffman et al. 2009). We used paired location data gathered from individuals that were GPS-collared both before and after fires to generate RSF models for female bighorn during summer and winter seasons. We conducted model selection using the best subset of predictor variables with competitive models $\Delta \mathrm{AIC} \leq 4$ (Arnold 2010) as well as consideration of highest Akaike's model weights $\left(\omega_{i}\right.$; Burnham and Anderson 2002). Due to insufficient sample sizes, male bighorn sheep RSF models were not considered.

Assuming that the error structure of residual values was not appropriate to generate reliable variances for model coefficients, we implemented random- $x$ resampling (Fox 2002) in a bootstrapping framework to assess coefficient variability (Efron 1979, Khurshid et al. 2005). Bootstrapping methods reflected Type2 resource selection (Thomas and Taylor 2006), in which discrete animals were the experimental units used to account for individual variation in RSF models. We randomly selected the same number of animals present in the original sample (with replacement), and used locations from these animals to populate response variables within the best models and generate new variable coefficient point estimates. We then estimated respective standard errors and $95 \%$ confidence intervals by encapsulating the mid-ninety-fifth percentile of each coefficient under 1000 bootstrap iterations. We validated RSFs by populating top model response variables using supplemental location data acquired from bighorns that collected data either before or after habitat alterations. We then assessed whether coefficient point estimates fell within bootstrapped confidence intervals generated from paired data. Finally, we determined significant habitat selection of fire-altered habitats if bootstrapped confidence intervals for the interaction term did not in- clude zero, and we created coefficient plots for visual comparisons among other predictor variables.

We supplemented habitat selection methods with ad hoc analyses that quantified the proportion of locations within independent fire treatments. We again used location data gathered from corresponding bighorn sheep before and after habitat alterations and conducted paired $t$-tests to identify changes in the proportion of locations within treated areas before and after fires. Unlike RSF models, we used paired data from males and females irrespective of season, and conducted tests that treated each fire independently to identify changes among prescribed burns or wildfire as an indication of effectiveness of treatment type.

\section{Survival Analysis}

We used the Kaplan-Meier product-limit estimator (K-M; Kaplan and Meier 1958) modified for staggered entry (Pollock et al. 1989), with variances computed following Greenwood (1926), to evaluate bighorn survival throughout the study, encompassing translocation efforts as well as the December 2011 capture until all GPS units detached by June 2013. We also report cause-specific mortalities of marked individuals from field observations and necropsies throughout the study period. We conducted a series of independent sample $t$-tests to compare overall bighorn mortality and cause-specific mortality with a suite of variables representing spatial responses of bighorn after fire including home range overlap of treated areas, changes in proportional use of treatment areas after fires, and home range expansion as relative change in home range size after fires.

Though the K-M and cause-specific data showed trends through the entire study period, tests only included data recovered from bighorns that were captured within the study area in $2011(n=24)$ that were potentially influenced by fire. We further restricted samples 
for which spatial changes before and after fires were quantified at an individual level using paired data $(n=16)$, including the change in home range size after fires (home range expansion) and the change in the proportion of locations within treated areas after fires as an index of selection. We categorized cause-specific mortality to include animals that died in connection with poor body condition $(n=4)$, and remaining mortalities into an "other" category $(n=5)$.

\section{RESULTS}

\section{Distributional Response to Fires}

When summarizing bighorn distributions, we found an average of $29 \%$ of bighorn home ranges $(n=24$, both $50 \%[0.29 \pm 0.06$; mean \pm $\mathrm{SE}]$ and $95 \%$ [0.29 \pm 0.06$]$ home range contours) overlapped fire-treated areas. Because the relative difference in home range size was quantified by dividing post-fire area by pre-fire area for each animal, a metric equal to 1 indicated no change in home range size and was used as the null hypothesis value in $t$-tests. We identified that bighorns $(n=16$, pre fire and post fire) increased their post-fire home range sizes by $\sim 200 \%\left(t_{15}=2.71, P=0.016\right)$ at the $50 \%$ contour $(2.97 \pm 0.73)$, and $\sim 250 \%\left(t_{15}=\right.$ $2.33, P=0.034)$ at the $95 \%$ contour $(3.53 \pm$ 1.09).

\section{Habitat Selection of Fire-Treated Areas}

We report paired datasets from 12 adult female bighorn to provide RSF model coefficient point estimates, SEs, and 95\% confidence intervals for summer and winter season models (Table 2). Location data used in the summer model included 11573 locations (mean per animal $=964$, range $=579$ to 1487 ), whereas winter model data consisted of 24620 locations (mean per animal $=2052$, range $=$ 1622 to 2640). Model selection procedures resulted in only slight differences in top per- forming model structures between summer and winter. In both cases, top models ranked well above competing model structures, outperforming competitive models by exhibiting $\omega_{i} \geq 0.998$, and $\triangle \mathrm{AIC}$ of 43.1 and 13.2 for summer and winter models, respectively. Coefficient plots revealed that confidence intervals encompassed point estimates from additional location data from $n=20$ (9605 locations, mean per animal $=480$, range $=82$ to 741) and $n=24$ (20504 locations, mean per animal $=854$, range $=215$ to 1480 ) individuals in summer and winter seasons, respectively, indicating that models validated well when tested with supplemental data (Figure 2).

Summer and winter resource selection were similar, with bighorn selecting for lower elevation habitats, and for east, south, and west aspects in relation to the north aspect reference (Figure 2). High correlation between slope and distance to escape terrain resulted in one variable constrained from inclusion in the same models during model selection procedures. However, bighorn selected for habitat with greater slopes in the summer, and similarly selected against increasing distances from escape terrain in winter, supporting the notion of bighorn reliance on close proximity to steep and rugged terrain (Figure 2). Female bighorn also selected habitats farther from roads in winter. Differences between pre-fire and postfire locations were identified in the winter model as well. In both models, no influence was found in the distance to burned areas, and the interaction term defined as the primary indicator of selection for fire-treated areas showed no influence on bighorn resource selection, with confidence intervals overlapping zero, and validation point estimates opposite point estimates derived in model construction (Figure 2).

Similar to results of RSF models, the proportion of locations before $(0.23 \pm 0.06)$ and after habitat $(0.30 \pm 0.05)$ alterations showed no difference when measured among combined fire events and before and after the initi- 
Table 2. Resource selection modeling results, including covariate estimates $(\beta)$, bootstrap-derived standard errors (SE), and $95 \%$ confidence intervals for 12 female bighorn sheep in the Seminoe Mountains, Wyoming, USA, from 2009 to 2013.

\begin{tabular}{|c|c|c|c|c|c|}
\hline \multirow[b]{2}{*}{ Season } & \multirow[b]{2}{*}{ Covariate } & \multirow[b]{2}{*}{$\beta$} & \multirow[b]{2}{*}{ SE } & \multicolumn{2}{|c|}{$95 \%$ Confidence interval } \\
\hline & & & & Lower limit & Upper limit \\
\hline \multirow{11}{*}{$\underset{\Xi}{\Xi}$} & intercept & -0.582 & NA & NA & NA \\
\hline & aspect* & & & & \\
\hline & east & 0.743 & 0.127 & 0.537 & 0.979 \\
\hline & south & 2.159 & 0.409 & 1.202 & 2.917 \\
\hline & west & 1.134 & 0.295 & 0.408 & 1.587 \\
\hline & dist_burn & -0.700 & 1.258 & -1.943 & 0.419 \\
\hline & dist_road & 0.678 & 0.267 & -0.026 & 1.003 \\
\hline & $\mathrm{elev}^{*}$ & -0.854 & 0.126 & -1.059 & -0.570 \\
\hline & pre.post & 0.487 & 0.759 & -0.056 & 2.115 \\
\hline & slope* & 0.704 & 0.176 & 0.396 & 1.054 \\
\hline & Int & -0.671 & 0.825 & -2.292 & 0.423 \\
\hline \multirow{11}{*}{ 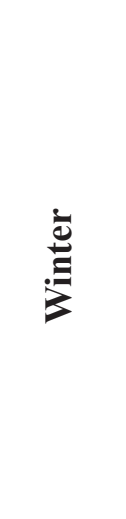 } & intercept & 0.820 & NA & NA & NA \\
\hline & aspect* & & & & \\
\hline & east & 0.651 & 0.313 & 0.177 & 1.126 \\
\hline & south & 2.064 & 0.897 & 1.171 & 2.835 \\
\hline & west & 0.524 & 0.733 & 0.058 & 1.369 \\
\hline & dist_burn & -0.111 & 0.615 & -1.223 & 0.697 \\
\hline & dist_escp* & -0.540 & 0.122 & -0.784 & -0.318 \\
\hline & dist_road* & 0.426 & 0.305 & 0.086 & 1.009 \\
\hline & elev & -0.453 & 0.718 & -1.298 & -0.013 \\
\hline & pre.post* & 0.311 & 0.285 & 0.043 & 1.060 \\
\hline & Int & -0.714 & 0.468 & -1.282 & 0.148 \\
\hline
\end{tabular}

* Indicates significant covariates.

ation of fires in May $2011\left(t_{15}=1.63, P=\right.$ 0.123 ). However, treating each fire independently provided some inference to specific use of treatment type. To be included in the sample, these tests required that animal locations be identified within independent treatment areas before, after, or before and after each fire. Results indicated that bighorn increased use of habitats altered with prescribed fires in 2011 and 2012 (Table 3). The first prescribed burn, in May 2011, resulted in an estimated increased use of $11 \%$, with all 11 individuals increasing the proportion of locations within the burned area after the treatment. The second prescribed fire, in March 2012, showed similar results, with an estimated increase of $7 \%$, and with 9 of 10 bighorns increasing pro- portional use. However, we found no difference in use of burned habitat from the wildfire event in July 2012 - although 5 of 9 bighorns increased proportional use, these changes ultimately resulted in an estimated $1 \%$ decrease in area used by bighorns after the wildfire event (Table 3 ).

\section{Demographic Response to Fires}

We documented 13 natural bighorn sheep mortalities (12 F, 1 M) from December 2009 to June 2013. Predation events were primarily attributed to mountain lions (Puma concolor; four of five documented predations). Other causes of mortality included an apparent fall from a cliff during winter 2010-2011, one 


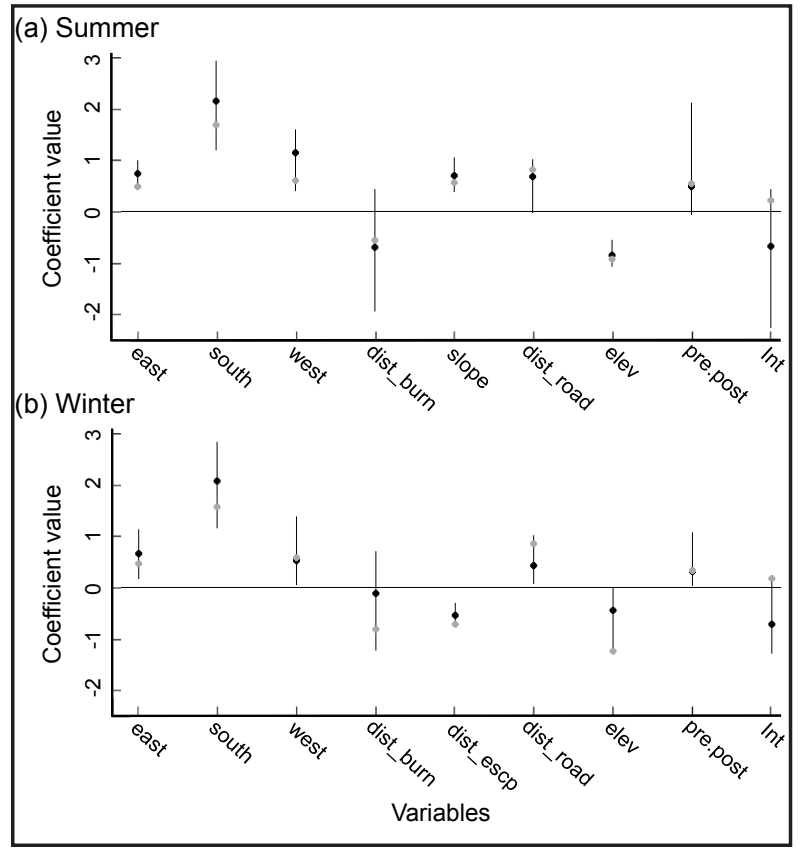

Figure 2. RSF model coefficient plots for female bighorn resource selection in the Seminoe Mountains, Wyoming, USA, from 2009 to 2013. a) Summer habitat selection. Point estimates and bootstrap-derived $95 \%$ confidence intervals were based on $n=12$ individuals (black), and validation estimates from $n=20$ individuals (grey points). b) Winter habitat selection. Point estimates and bootstrap-derived $95 \%$ confidence intervals were based on $n=12$ individuals (black), and validation estimates from $n=24$ individuals (grey points). Note that confidence intervals for interaction terms (far right) overlap zero, indicating that bighorns did not select fire-treated habitats during summer or winter seasons. male bighorn entangled in a wire fence during winter 2012-2013, and one unknown mortality in summer 2013. A notable portion of mortality occurred during spring 2013, in which 5 bighorn died within a two-day period in midApril. On further examination, these animals had little to no apparent fat reserves, resulting in extreme emaciation, and examination of bone marrow content further indicated signs of overall poor body condition. Although survival estimates remained relatively high early in the study, mortalities documented in 2013 resulted in a precipitous decrease in survival, resulting in greater than $30 \%$ mortality from radio-collared bighorns (Figure 3).

Due to the marked decrease in bighorn survival after alterations, we conducted a series of tests to identify potential correlations between overall survival and cause-specific mortalities, and various bighorn responses to altered habitats. We found that bighorns that died $(n=9)$ increased their distributions more than bighorns that survived after fires $(n=15$; Table 4). However, this correlation was not identified when tested against the cause of mortality. In addition, the change in proportion of locations in treated areas after fire was not different between bighorns that survived or that died, or on the cause of mortalities (Table 4). Finally, we found evidence suggesting that bighorns that died had a higher proportion of home range overlap with burned areas $\left(t_{22}=\right.$ 1.51, $P=0.146$ ) and, further, that bighorn mortality associated with poor body condition

Table 3. Estimates, standard errors (SE), range in estimates, d.f., and $P$-values from paired $t$-tests of the proportion of bighorn locations within treated areas before (pre-fire) and after (post-fire) fire events in the Seminoe Mountains, Wyoming, USA, from 2009 to 2013.

\begin{tabular}{|c|c|c|c|c|c|c|c|c|c|}
\hline \multirow[b]{2}{*}{ Habitat treatment } & \multicolumn{3}{|c|}{ Pre-fire } & \multicolumn{3}{|c|}{ Post-fire } & \multirow[b]{2}{*}{ d.f. } & \multirow[b]{2}{*}{$t$ stat } & \multirow[b]{2}{*}{$\boldsymbol{P}$} \\
\hline & Est. & SE & Range & Est. & SE & Range & & & \\
\hline $\begin{array}{l}\text { Prescribed burn } \\
\text { (May 2011) }\end{array}$ & 0.03 & 0.01 & 0.00 to 0.10 & 0.14 & 0.02 & 0.01 to 0.28 & 10 & -5.98 & $\leq 0.001$ \\
\hline $\begin{array}{l}\text { Prescribed burn } \\
\text { (Mar 2012) }\end{array}$ & 0.06 & 0.01 & $>0.01$ to 0.11 & 0.14 & 0.02 & $>0.01$ to 0.19 & 9 & -5.37 & $\leq 0.001$ \\
\hline $\begin{array}{l}\text { Wildfire } \\
\text { (Jul 2012) }\end{array}$ & 0.24 & 0.08 & 0.00 to 0.69 & 0.23 & 0.09 & 0.00 to 0.54 & 8 & 0.30 & 0.771 \\
\hline
\end{tabular}




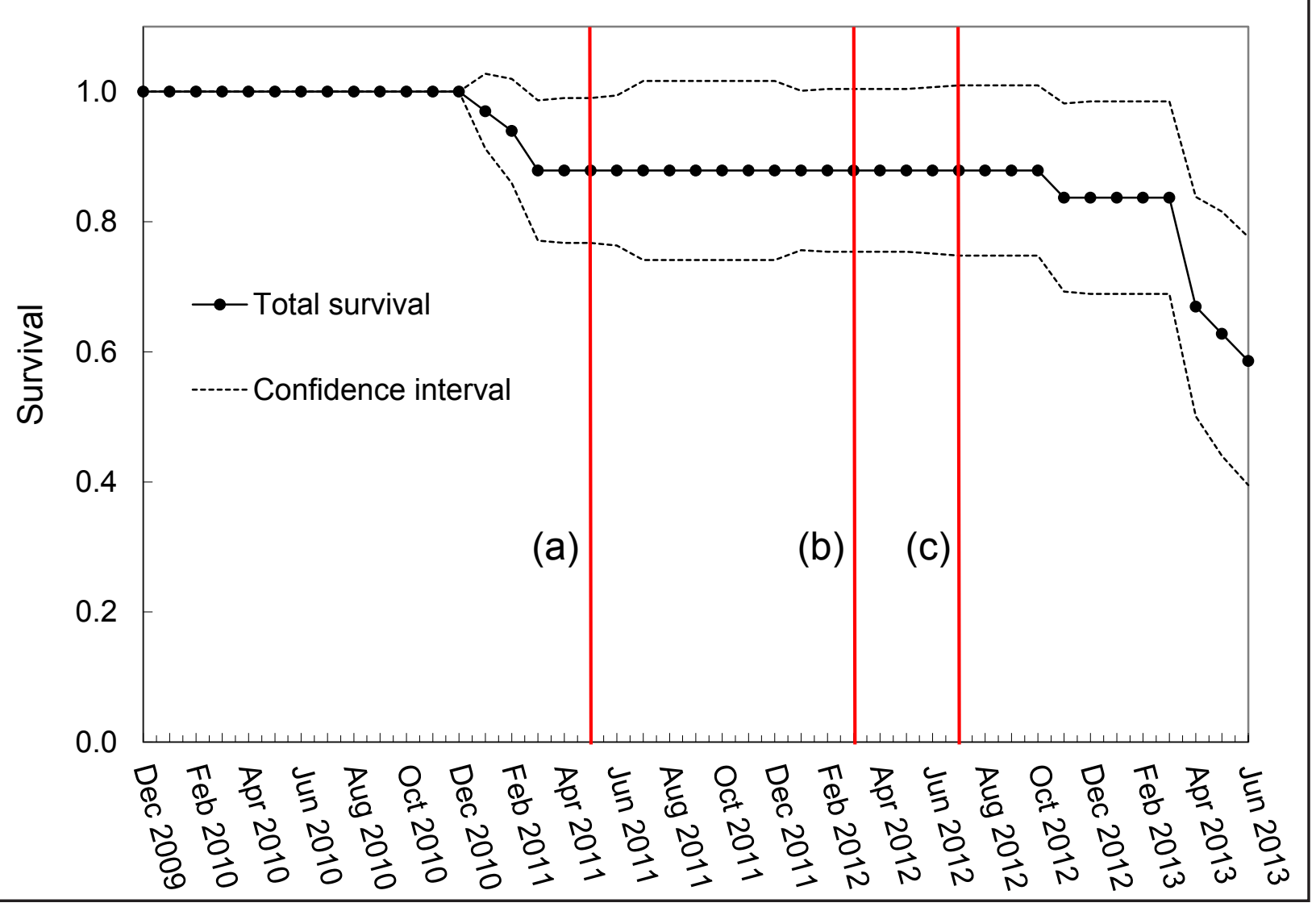

Figure 3. Staggered-entry Kaplan-Meier survival estimates of 48 radio-collared bighorn sheep (38 F, 10 M) in the Seminoe Mountains, Wyoming, USA from 2009 to 2013. Vertical red lines represent fire events including a) May 2011 prescribed fire, b) March 2012 prescribed fire, and c) July 2012 wildfire.

had higher home range overlap with burned areas $\left(t_{7}=-2.44, P=0.045\right.$; Table 4$)$.

\section{DISCUSSION}

We implemented a structured approach to describe the impacts of fire-mediated habitat alterations to bighorn sheep in our study area. We analyzed changes in distribution, quantified changes in use, and investigated selection for treated habitats. We correlated these responses to survival and found evidence that treatment type (i.e., prescribed or wildfire) had differing short-term impacts to overall bighorn success, likely due to differences associated with the lack of control and targeted intent, coverage, environmental conditions, size, and timing of the wildfire. Findings from our study align well with research documenting the po- tential for positive or negative responses of bighorn sheep to fire-treated habitats (Tesky 1993).

Results from distributional responses indicated that bighorns expanded post-fire home ranges. These findings lend support to our prediction that habitat treatments should cause an increase in space use by bighorn sheep and an expansion of home range area. This expansion could be attributed to bighorns partitioning overall space use by increasing use of adjacent areas with improved habitat after treatments while maintaining a portion of original space use due to other essential habitat requirements (e.g., proximity to escape terrain). On the contrary, bighorn expansion may be an indication that bighorns attempted to avoid burned habitats but were unwilling to venture far from other vital habitat components. Evi- 
Table 4. Independent 2-sample $t$-tests comparing bighorn distribution and habitat use by animals that survived or died and cause-specific mortality of bighorn sheep after the initiation of fire-mediated habitat alterations in the Seminoe Mountains, Wyoming, USA from May 2011 to June 2013.

\begin{tabular}{|c|c|c|c|c|c|c|c|c|c|}
\hline \multirow[b]{3}{*}{ Variable } & \multicolumn{6}{|c|}{ Survival } & \multirow[b]{3}{*}{ d.f. } & \multirow[b]{3}{*}{$t$ stat } & \multirow[b]{3}{*}{$P$} \\
\hline & \multicolumn{3}{|c|}{ Survived } & \multicolumn{3}{|c|}{ Died } & & & \\
\hline & Est. & SE & Range & Est. & SE & Range & & & \\
\hline $\begin{array}{l}\text { Relative home range } \\
\text { increase after fires } \\
\text { (95\% contour) }\end{array}$ & 1.48 & 0.36 & $\begin{array}{c}0.24 \text { to } \\
3.40\end{array}$ & 5.48 & 1.64 & $\begin{array}{c}2.60 \text { to } \\
12.80\end{array}$ & 14 & 2.69 & 0.018 \\
\hline $\begin{array}{l}\text { Relative home range } \\
\text { overlap with treated } \\
\text { areas }(95 \% \text { contour) }\end{array}$ & 0.25 & 0.04 & $\begin{array}{c}0.00 \text { to } \\
0.48\end{array}$ & 0.36 & 0.06 & $\begin{array}{c}0.00 \text { to } \\
0.51\end{array}$ & 22 & 1.51 & 0.146 \\
\hline \multirow[t]{4}{*}{$\begin{array}{l}\text { Selection for treated } \\
\text { habitat (change in } \\
\text { proportion of locations } \\
\text { within treated areas } \\
\text { after fires) }\end{array}$} & 0.06 & 0.07 & $\begin{array}{c}-0.41 \text { to } \\
0.38\end{array}$ & 0.08 & 0.05 & $\begin{array}{c}-0.09 \text { to } \\
0.28\end{array}$ & 14 & 0.26 & 0.801 \\
\hline & \multicolumn{6}{|c|}{$\begin{array}{c}\text { Cause-specific mortality } \\
\end{array}$} & & & \\
\hline & \multicolumn{3}{|c|}{ Poor body condition } & \multicolumn{3}{|c|}{ Other } & & & \\
\hline & Est. & SE & Range & Est. & SE & Range & d.f. & $t$ stat & $\boldsymbol{P}$ \\
\hline $\begin{array}{l}\text { Relative home range } \\
\text { increase after fires } \\
\text { ( } 95 \% \text { contour) }\end{array}$ & 5.08 & 2.63 & $\begin{array}{l}1.34 \text { to } \\
10.15\end{array}$ & 5.79 & 2.42 & $\begin{array}{l}2.54 \text { to } \\
12.80\end{array}$ & 5 & 0.19 & 0.854 \\
\hline $\begin{array}{l}\text { Relative home range } \\
\text { overlap with treated } \\
\text { area ( } 95 \% \text { contour) }\end{array}$ & 0.48 & 0.03 & $\begin{array}{c}0.39 \text { to } \\
0.53\end{array}$ & 0.26 & 0.07 & $\begin{array}{c}0.00 \text { to } \\
0.39\end{array}$ & 7 & -2.44 & 0.045 \\
\hline $\begin{array}{l}\text { Selection for treated } \\
\text { habitat (change in } \\
\text { proportion of locations } \\
\text { within treated areas } \\
\text { after fires) }\end{array}$ & 0.00 & 0.04 & $\begin{array}{c}-0.09 \text { to } \\
0.05\end{array}$ & 0.15 & 0.06 & $\begin{array}{c}0.00 \text { to } \\
0.29\end{array}$ & 5 & 1.81 & 0.130 \\
\hline
\end{tabular}

dence suggests that increased energy demands of animals require larger areas for food gathering (McNab 1963) and that animals often increase home range size when nutritional resources are scarce (Ford 1983, Tufto et al. 1996). Accordingly, an inverse relationship often exists between available forage biomass or food resources and home range size (Anderson et al. 2005, Corriale et al. 2013). Under these assertions, if habitat quality had improved, bighorns might have restricted distributions if they positively responded to habitat treatments conducted within current home ranges - able to access important resources while limiting energy expenditures. Thus, although our prediction that bighorns would expand distribution was supported, in certain conditions it may have been under negative implications on bighorn fitness.

Although home range area increased after fires, RSF modeling showed no overall selection for burned areas. Supplemental analyses testing the change in proportion of locations in treated areas after fires did find that bighorn use increased after both prescribed burn treatments, but not after the wildfire. While specific fires may have influenced habitat use, these tests did not account for additional habitat variables that influenced habitat selection as shown in RSF models. Also, examining each fire independently may overlook the influence one fire may have had on another. Habitat selection for fires may also have been obscured by the extensive area or spatial coverage of 
burns, which encompassed much bighorn distribution before and after fires within the study area. In this case, bighorn selection would not be easily identified by change in use patterns. Overall, we were unable to positively identify habitat selection for treated areas, although we did find increased use in areas treated with prescribed burning.

A key assumption within habitat selection models is that animals select habitat to benefit overall fitness (Manly et al. 2002), and we used analyses correlating demographic response of bighorn sheep to measured responses in distributional shifts and potential habitat selection. Kaplan-Meier survival estimates showed that survival decreased more after the initiation of habitat alterations than before, and poor body condition tied to mortality incidence after the wildfire event implicated that habitat treatments decrease foraging efficiency of some bighorns. After fire events, we found that bighorns that died had increased their home range sizes more than those that expanded home ranges to a lesser degree. In addition, it was suspected that animals that died showed higher overlap of home ranges with treated areas, which was verified when examining animals that died in poor body condition. These results are congruent with the example previously described, in which bighorns expanded home ranges not as an opportunity to increase use of habitat but in an attempt to gain resources required to maintain fitness levels. Thus, our prediction of high bighorn survival commensurate with treated habitats was not supported.

Because we found evidence supporting increased use of prescribed burns but no evidence that it negatively influenced bighorn survival, we determined that prescribed burning likely contributed to bighorns expanding distribution via selection for treated habitat. Although specific habitat selection through RSF modeling revealed no selection for treated areas as a whole, increased use of this area under optimal foraging theory (Stephens and
Krebs 1986) likely did not hinder bighorn fitness, and we found no increase in mortality during this time. Likewise, in a review of case studies on influences of fire on bighorn sheep populations, Peek et al. (1985) provide many examples in which fire-treated habitats benefited bighorn sheep populations. However, we postulate that wildfire that occurred late in the study negatively impacted bighorn sheep when an apparent decrease in survival was documented.

High burn severity has the potential to alter forage composition and delay vegetative response after fires (Miller 2000, Lentile et al. 2007). While data were not available to quantify burn severity for all fire treatments in our study area, we found only minimal differences in the proportion of high burn severity between the prescribed fire in 2011 and the wildfire in $2012(1.8 \%$ and $1.9 \%$, respectively; MTBS 2015). However, post-fire drought conditions delay the recovery of vegetative communities (Huffman 2004) and drier conditions often increase the spatial coverage of uncontrolled fires (Miller 2000), both characteristics of the wildfire event. Although our focus was specific to the impact of the wildfire event, it is important to consider the interplay between drought and wildfire during our study, as well as the temporal limits of data collection after the wildfire occurred. Specifically, the impact of drought alone likely influenced foraging behavior and fitness of bighorn sheep, and may be considered proximal to the results we obtained after the wildfire event. In addition, extended temporal assessments after the cessation of fire treatments (e.g., multiple seasons of recovery) might enable inference to future bighorn success. However, we postulate that the interaction between drought and wildfire drastically altered immediate foraging conditions for animals utilizing areas impacted by wildfire, when evidence suggested direct negative impacts on bighorn sheep due to the complete coverage of the burn and removal of foraging options. 
Climate patterns for the study area show a $30 \mathrm{yr}$ precipitation average of $36 \mathrm{~cm}$ annually. However, extreme drought conditions in 2012 revealed the lowest annual precipitation recorded since $1901(<21 \mathrm{~cm})$. Therefore, vegetative response after fires in 2012 was extremely low. In particular, the wildfire that occurred in July caused extensive habitat loss, allowing sparse vegetative recovery before winter 2012-2013 (see Figure 4). In addition, the extent $\left(\sim 12.6 \mathrm{~km}^{2}\right)$ and contiguous coverage of the wildfire was greater than that of controlled prescribed fires $\left(\sim 7.5 \mathrm{~km}^{2}\right)$ that presented mosaic fire patterns across the landscape (see Figure 1). While we concede that our study was limited by the inability to conduct vegetative assessments before and after fires, field observations revealed striking differences in the recovery of vegetative communities during the drought in 2012. We suggest that bighorn expanded distribution at this time to gain access to remaining forage but were unwilling to vacate burned areas completely, resulting in reduced fat reserves while increasing energy expenditures. Largely dependent on the size, intensity, and completeness of burns, detrimental short-term effects of fire have been described in which destruction of winter browse forage or reduced availability of forage can limit wildlife populations, especially in scenarios with limited alternative wintering habitats (Klein 1982, Klebenow 1985). Specifically regarding bighorn sheep, negative impacts of fires can occur when forage species cannot respond, species that provide key nutrients are eliminated, or when too much area is burned and inadequate forage remains until the next growing season (Peek et al. 1985). Under similar conditions in our study area, bighorn fitness was likely suppressed, leaving them vulnerable to weather conditions in early 2013.

Practitioners implementing prescribed burning to support bighorn sheep face many challenges. The unpredictable nature of weather patterns makes optimal timing of burns difficult, with post-fire recovery heavily dependent on ever-increasing stochastic tendencies in climate regimes, particularly drought (Engle and Bultsma 1984). We rec-

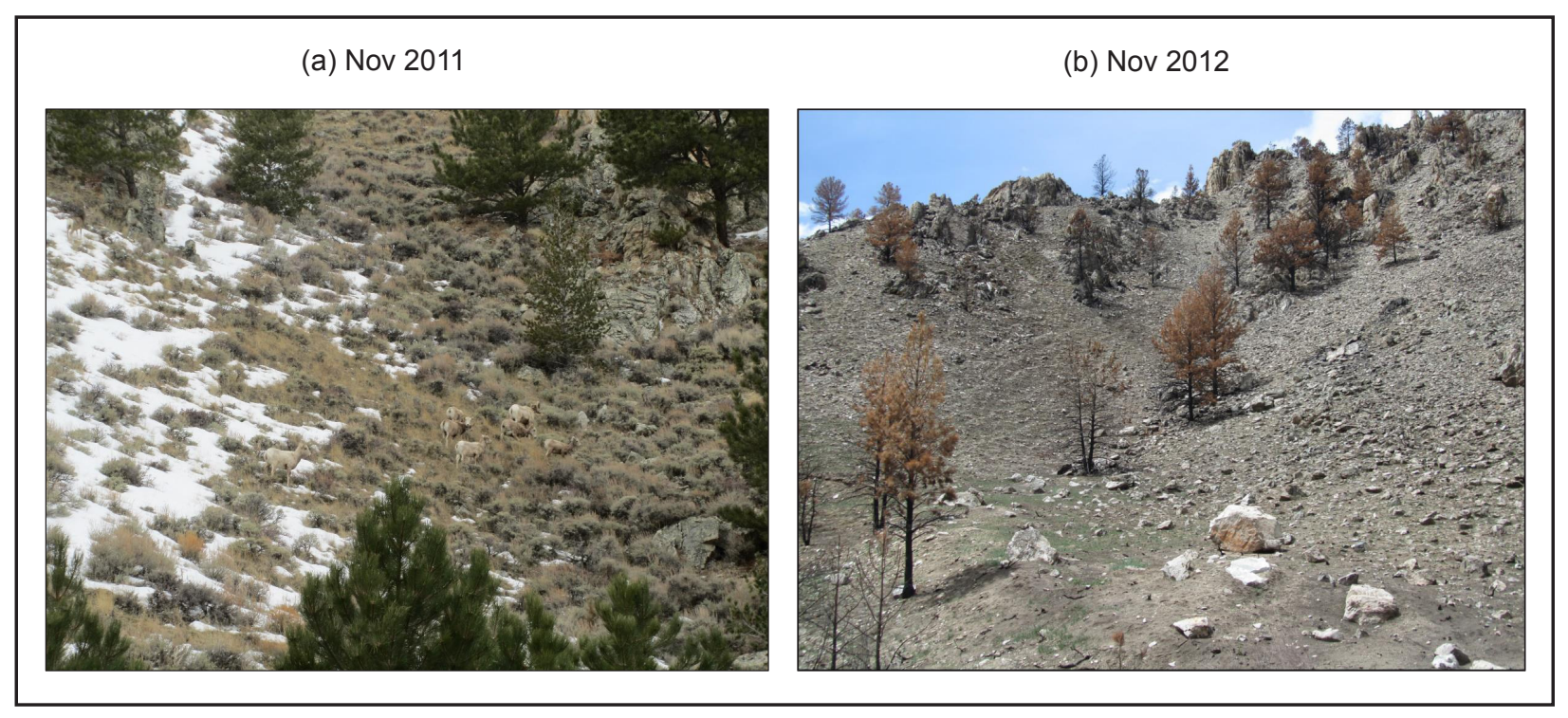

Figure 4. Photos of a northeast-facing slope taken before and after a wildfire event in the Seminoe Mountains, Wyoming, USA, in July 2012. a) Photo taken November 2011 before wildfire event. Note bighorn sheep in mixed sagebrush habitat. b) Photo taken November 2012 after wildfire event. Note complete removal of shrub component with little available herbaceous forage preceding winter season. 
ommend conducting prescribed fires before bighorn reintroductions, or conducting prescribed burns on a relatively small scale and rotational basis to avoid potentially impeding foraging options. Moreover, if objectives are set to support bighorn populations by opening habitats restricted by timber encroachment, mechanical treatments such as clear-cut logging have been shown to increase habitat use by bighorns to a higher degree than burning alone (Smith et al. 1999).

\section{ACKNOWLEDGEMENTS}

This work was supported by the University of Wyoming, Wyoming Game and Fish Department, Wyoming Governor's Big Game License Coalition, and Wyoming Wild Sheep Foundation. The authors thank S.E. Albeke, D.D. Bjornlie, C.B. Buchanan, T.L. McDonald, G.S. Hiatt, K.T. Smith, and L.A. Varelas for logistical support, data management, and analysis techniques.

\section{LITERATURE CITED}

Anderson, D.P., J.D. Forester, M.G. Turner, J.L. Frair, E.H. Merrill, D. Fortin, J.S. Mao, and M.S. Boyce. 2005. Factors influencing female home range sizes in elk (Cervus elaphus) in North American landscapes. Landscape Ecology 20: 257-271. doi: 10.1007/s10980-005-0062-8

Arnold, T.W. 2010. Uninformative parameters and model selection using Akaike's information criterion. Journal of Wildlife Management 74: 1175-1178. doi: 10.2193/2009-367

Bleich, V.C., J.D. Wehausen, and S.A. Holl. 1990. Desert-dwelling mountain sheep: conservation implications of a naturally fragmented distribution. Conservation Biology 4: 383-390. doi: $10.1111 /$ j.1523-1739.1990.tb00312.x

Burnham, K.P., and D.R. Anderson. 2002. Model selection and multimodel inference. Second edition. Springer-Verlag, New York, New York, USA.

Clapp, J.G., and J.L. Beck. 2015. Evaluating distributional shifts in home range estimates. Ecology and Evolution 5: 3869-3878. doi: 10.1002/ece3.1655

Clapp, J.G., J.L. Beck, and K.G. Gerow. 2014. Post-release acclimation of translocated low-elevation, non-migratory bighorn sheep. Wildlife Society Bulletin 38: 657-663.

Cook, J.G., T.J. Hershey, and L.L. Irwin. 1994. Vegetative response to burning on Wyoming mountain-shrub big game ranges. Journal of Range Management 47: 296-302. doi: $10.2307 / 4002550$

Corriale, M.J., E. Muschetto, and E.A. Herrera. 2013. Influence of group sizes and food resources in home-range sizes of capybaras from Argentina. Journal of Mammalogy 94: 19-28. doi: 10.1644/12-MAMM-A-030.1

DeCesare, N.J., and D.H. Pletscher. 2006. Movements, connectivity, and resource selection of Rocky Mountain bighorn sheep. Journal of Mammalogy 87: 531-538. doi: 10.1644/05-MAMM-A-259R1.1

DeWitt, J.B., and J.V. Derby Jr. 1955. Changes in nutritive value of browse plants following forest fires. Journal of Wildlife Management 19: 65-70. doi: 10.2307/3797554

Efron, B. 1979. Bootstrap methods: another look at the jackknife. Annals of Statistics 7: 1-26. doi: $10.1214 / \mathrm{aos} / 1176344552$

Engle, D.M., and P.M. Bultsma. 1984. Burning of northern mixed prairie during drought. Journal of Range Management 37: 398-401. doi: 10.2307/3899623

Ford, R.G. 1983. Home range in a patchy environment: optimal foraging predictions. American Zoologist 23: 315-326. doi: 10.1093/icb/23.2.315 
Foster, C.L. 2005. Wild sheep capture guidelines. Biennial Symposium of North American Wild Sheep and Goat Council 14: 211-282.

Fox, J. 2002. An R and S-PLUS companion to applied regression. Sage Publications, Thousand Oaks, California, USA.

Greenwood, M. 1926. A report on the natural duration of cancer. Ministry of Health reports on public health and medical subjects, no. 33. His Majesty's Stationery Office, London, England, United Kingdom.

Hall, L.S., P.R. Krausman, and M.L. Morrison. 1997. The habitat concept and a plea for standard terminology. Wildlife Society Bulletin 25: 173-182.

Hiatt, G. 1997. Ferris-Seminoe bighorn sheep lambing study: a compilation and summation of data collected by M. Benker, P. Jones, and L. Kinter. Wyoming Game and Fish Department, Cheyenne, Wyoming, USA.

Hobbs, N.T., and R.A. Spowart. 1984. Effects of prescribed fire on nutrition of mountain sheep and mule deer during winter and spring. Journal of Wildlife Management 48: 551-560. doi: $10.2307 / 3801188$

Horne, J.S., E.O. Garton, S.M. Krone, and J.S. Lewis. 2007. Analyzing animal movements using Brownian bridges. Ecology 88: 2354-2363. doi: 10.1890/06-0957.1

Huffman, D.W., and M.M. Moore. 2004. Responses of Fendler ceanothus to overstory thinning, prescribed fire, and drought in an Arizona ponderosa pine forest. Forest Ecology and Management 198: 105-115. doi: 10.1016/j.foreco.2004.03.040

Johnson, T.L., and D.M. Swift. 2000. A test of a habitat evaluation procedure for Rocky Mountain bighorn sheep. Restoration Ecology 8: 47-56. doi: 10.1046/j.1526-100x.2000.80065.x

Kaplan, E.L., and P. Meier. 1958. Nonparametric estimation from incomplete observations. Journal of the American Statistical Association 53: 457-481. doi: 10.1080/01621459.1958.10501452

Kauffman, M.J., A.B. Courtemanch, and A. Rutledge. 2009. Resource selection and group association of translocated bighorn sheep in north-central Wyoming: does source herd matter? Wyoming Cooperative Fish and Wildlife Research Unit, University of Wyoming, Laramie, USA.

Khurshid, A., M.A. Ageel, and R.A. Lodhi. 2005. On confidence intervals for the negative binomial distribution. Revista Investigación Operacional 26: 59-70.

Klebenow, D.A. 1985. Big game response to fire in sagebrush-grass rangelands. Pages 53-57 in: K. Sanders and J. Durham, editors. Proceedings of a symposium-Rangeland Fire Effects. US Department of the Interior, Bureau of Land Management, 27-29 November 1984, Boise, Idaho, USA.

Klein, D.R. 1982. Fire, lichens and caribou. Journal of Range Management 35: 390-395. doi: $10.2307 / 3898326$

Lentile, L.B., P. Morgan, A.T. Hudak, M.J. Bobbitt, S.A. Lewis, A.M.S. Smith, and P.R. Robichaud. 2007. Burn severity and vegetation response following eight wildfires across the western US. Fire Ecology 3(1): 91-108. doi: 10.4996/fireecology.0301091

Manly, B.F., L. McDonald, D. Thomas, T. McDonald, and W. Erickson. 2002. Resource selection by animals: statistical design and analysis for field studies. Second edition. Kluwer Academic Publishers, Boston, Massachusetts, USA.

McNab, B.K. 1963. Bioenergetics and the determination of home range size. The American Naturalist 97: 133-140. doi: 10.1086/282264 
McWhirter, D., S. Smith, E. Merrill, and L. Irwin. 1992. Foraging behavior and vegetation responses to prescribed burning on bighorn sheep winter range. Proceedings of the Biennial Symposium on Northern Wild Sheep and Goat Council 8: 264-278.

Miller, M. 2000. Fire autecology. Pages 9-34 in: J.K. Brown and J.K. Smith, editors. Wildland fire in ecosystems: effects of fire on flora. General Technical Report RMRS-GTR-42-vol. 2, USDA Forest Service, Rocky Mountain Research Station, Ogden, Utah, USA.

Millspaugh, J.J., R.M. Nelson, L. McDonald, J.M. Marzluff, R.A. Gitzen, C.D. Rittenhouse, M.W. Hubbard, and S.L. Sheriff. 2006. Analysis of resource selection using utilization distributions. Journal of Wildlife Management 70: 384-395. doi: 10.2193/0022-541X(2006)70[384: AORSUU]2.0.CO;2

MTBS [Monitoring Trends in Burn Severity]. 2015. MTBS Project, USDA Forest Service and US Geological Survey. <http://www.mtbs.gov/data/individualfiredata.html>. Accessed 25 September 2015.

Nielson, R.M., and H. Sawyer. 2013. Estimating resource selection with count data. Ecology and Evolution 3: 2233-2240. doi: 10.1002/ece3.617

Nielson, R.M., H. Sawyer, and T.L. McDonald. 2013. BBMM: Brownian bridge movement model for estimating the movement path of an animal using discrete location data. $\mathrm{R}$ foundation for Statistical Computing, Vienna, Austria.

Nielson, R.M., B.F.J. Manly, L.L. McDonald, H. Sawyer, and T.L. McDonald. 2009. Estimating habitat selection when GPS fix success is less than 100\%. Ecology 90: 2956-2962. doi: $10.1890 / 08-1562.1$

Ough, W.D., and J.C. deVos Jr. 1986. Intermountain travel corridors and their management implications for bighorn sheep. Desert Bighorn Council Transactions 28: 32-36.

Osborne, P.E., and P.J. Seddon. 2012. Selecting suitable habitats for reintroductions: variation, change, and the role of species distribution modelling. Pages 74-104 in: J. Ewen, D. Armstrong, K. Parker, and P. Seddon, editors. Reintroduction biology: integrating science and management. John Wiley and Sons, West Sussex, England, United Kingdom. doi: 10.1002/9781444355833.ch3

Peek, J.M., D.A. Demarchi, R.A. Demarchi, and D.E. Stucker. 1985. Bighorn sheep and fire: seven case histories. Pages 36-43 in: J.E. Lotan and J.K. Brown, compilers. Symposium proceedings - fire's effect on wildlife habitat. General Technical Report INT-GTR-186, USDA Forest Service, Intermountain Research Station, Ogden, Utah, USA.

Pollock, K.H., S.R. Winterstein, C.M. Bunck, and P.D. Curtis. 1989. Survival analysis in telemetry studies: the staggered entry design. Journal of Wildlife Management 53: 7-15. doi: $10.2307 / 3801296$

R Development Core Team. 2012. R: a language and environment for statistical computing. $<$ http://www.R-project.org>. Accessed 14 November 2013.

Risenhoover, K.L., J.A. Bailey, and L.A. Wakelyn. 1988. Assessing the Rocky Mountain bighorn sheep management problem. Wildlife Society Bulletin 16: 346-352.

Sawyer, H., M.J. Kauffman, and R.M. Nielson. 2009. Influence of well pad activity on the winter habitat selection patterns of mule deer. Journal of Wildlife Management 73: 1052-1061. doi: 10.2193/2008-478

Sawyer, H., R.M. Nielson, F.G. Lindzey, and L.L. McDonald. 2006. Winter habitat selection of mule deer before and during development of a natural gas field. Journal of Wildlife Management 70: 396-403. doi: 10.2193/0022-541X(2006)70[396:WHSOMD]2.0.CO;2

Seip, D.R., and F.L. Bunnell. 1985. Nutrition of Stone's sheep on burned and unburned ranges. Journal of Wildlife Management 49: 397-405. doi: 10.2307/3801541 
Sikes, R.S., and W.L. Gannon. 2011. Guidelines of the American Society of Mammalogists for the use of wild mammals in research. Journal of Mammalogy 92: 235-253. doi: 10.1644/10-MAMM-F-355.1

Singer, F.J., C.M. Papouchis, and K.K. Symonds. 2000. Translocations as a tool for restoring populations of bighorn sheep. Restoration Ecology 8: 6-13. doi: 10.1046/j.1526-100x.2000.80061.x

Smith, T.S., P.J. Hardin, and J.T. Flinders. 1999. Response of bighorn sheep to clear-cut logging and prescribed burning. Wildlife Society Bulletin 27: 840-845.

Stephens, D.W., and J.R. Krebs. 1986. Foraging theory. Princeton University Press, New Jersey, USA.

Tabachnick, B.G., and L.S. Fidell. 2001. Using multivariate statistics. Fourth edition. Allyn and Bacon, Boston, Massachusetts, USA.

Tesky, J.L. 1993. Ovis canadensis. Fire Effects Information System. US Department of Agriculture, Forest Service, Rocky Mountain Research Station, Fire Sciences Laboratory. <http:// www.fs.fed.us/database/feis>. Accessed 27 September 2015.

Thomas, D.L., and E.J. Taylor. 2006. Study designs and tests for comparing resource use and availability II. Journal of Wildlife Management 70: 324-336. doi: 10.2193/0022-541X(2006)70[324:SDATFC]2.0.CO;2

Tufto, J., R. Anderson, and J. Linnell. 1996. Habitat use and ecological correlates of home range size in a small cervid: the roe deer. Journal of Animal Ecology 65: 715-724. doi: $10.2307 / 5670$

Van Dyke, F., and J.A. Darragh. 2007. Response of elk to changes in plant production and nutrition following prescribed burning. Journal of Wildlife Management 71: 23-29. doi: $10.2193 / 2005-464$

Western Regional Climate Center. 2013. Western US Climate Summaries-NOAA coop stations. <http://www.wrcc.dri.edu>. Accessed 9 June 2013.

White, G.C., and R.E. Bennetts. 1996. Analysis of frequency count data using the negative binomial distribution. Ecology 77: 2549-2557. doi: 10.2307/2265753 